\title{
Prevalence of vitamin D deficiency in the pregnant women: an observational study in Shanghai, China
}

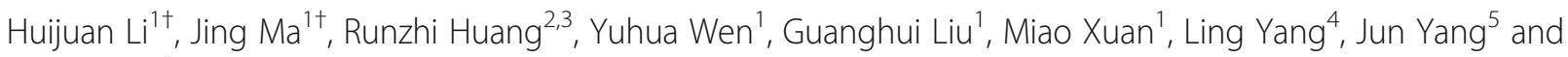
Lige Song ${ }^{1 *}$

\begin{abstract}
Background: Maternal vitamin D deficiency has been a worldwide concern in recent years. However the epidemiological data of vitamin D deficiency among large group of Chinese pregnant women is limited. This study is to evaluate the prevalence of vitamin D deficiency among pregnant women in Shanghai, China and to analyze the association of vitamin D status with some pregnancy outcomes (gestational diabetes and low birth weight).

Methods: A total of 34,417 pregnant women in Shanghai were included in this study from January 2014 to December 2017, and the serum 25-hydroxyvitamin D [25(OH)D] concentrations were measured at 16th week of gestation by electrochemiluminescence assay. Seventy five grams of glucose was used to conduct oral glucose tolerance test during 24-28th week of gestational in all enrolled persons and the birth weight of newborns was recorded.

Results: The median serum $25(\mathrm{OH})$ D concentration in the pregnant women during 4 years was $42.87 \mathrm{nmol} / \mathrm{L}(32.88-$ $51.90 \mathrm{nmol} / \mathrm{L}) .9 .9 \%$ of the population were severe vitamin $\mathrm{D}$ deficient $[25(\mathrm{OH}) \mathrm{D}<25 \mathrm{nmol} / \mathrm{L}], 60.1 \%$ were deficient [25 $\mathrm{nmol} / \mathrm{L} \leq 25(\mathrm{OH}) \mathrm{D}<50 \mathrm{nmol} / \mathrm{L}], 28.4 \%$ were insufficient $[50 \mathrm{nmol} / \mathrm{L} \leq 25(\mathrm{OH}) \mathrm{D}<75 \mathrm{nmol} / \mathrm{L}]$ and only $1.6 \%$ of the enrolled population reached the level of adequate $[25(\mathrm{OH}) \mathrm{D} \geq 75 \mathrm{nmol} / \mathrm{L}]$. Serum $25(\mathrm{OH}) \mathrm{D}$ concentrations showed significant difference among seasons with the highest level in winter and the lowest level in summer. Women with advanced maternal age were more likely to have better vitamin D status compared with younger women. The $25(\mathrm{OH})$ D levels were significantly different among 2014-2017. The year of 2017 had the highest 25(OH) D level with the median serum concentration reaching $47.80 \mathrm{nmol} / \mathrm{L}(41.00-55.00 \mathrm{nmol} / \mathrm{L})$, while the lowest appeared in 2016 which has median 25(OH) D concentration at $38.87 \mathrm{nmol} / \mathrm{L}(28.76-49.97 \mathrm{nmol} / \mathrm{L})$. No relations were found between the $25(\mathrm{OH}) \mathrm{D}$ status and the rate of gestational diabetes or low birth weight of newborns.
\end{abstract}

Conclusion: Pregnant women in Shanghai were generally deficient in vitamin D status and the level of vitamin D was related to season and age. No evidence showed vitamin D deficiency in pregnant women contributes to the rate of gestational diabetes or low birth weight of newborns in this study. These results suggest that most of the pregnant women may need vitamin D supplementation to achieve adequate vitamin D level.

Keywords: Vitamin D deficiency, Prevalence, Pregnancy, Observational study

\footnotetext{
* Correspondence: 6songlige@tongji.edu.cn

${ }^{\dagger}$ Huijuan Li and Jing Ma contributed equally to this work.

'Department of Endocrinology, Tongji Hospital, Tongji University School of Medicine, Shanghai 200065, China

Full list of author information is available at the end of the article
}

(c) The Author(s). 2020 Open Access This article is licensed under a Creative Commons Attribution 4.0 International License, which permits use, sharing, adaptation, distribution and reproduction in any medium or format, as long as you give appropriate credit to the original author(s) and the source, provide a link to the Creative Commons licence, and indicate if changes were made. The images or other third party material in this article are included in the article's Creative Commons licence, unless indicated otherwise in a credit line to the material. If material is not included in the article's Creative Commons licence and your intended use is not permitted by statutory regulation or exceeds the permitted use, you will need to obtain permission directly from the copyright holder. To view a copy of this licence, visit http://creativecommons.org/licenses/by/4.0/. The Creative Commons Public Domain Dedication waiver (http://creativecommons.org/publicdomain/zero/1.0/) applies to the data made available in this article, unless otherwise stated in a credit line to the data. 


\section{Background}

Vitamin D has been recognized as one of the most important biological regulators of calcium homeostasis and it has great influence on bone and mineral metabolism in mammals. However, based on the evidence that the vitamin D receptor expressed in multiple cells and tissues and the wide distribution of 1-alpha-hydroxylase, a key enzyme for 1,25-dyhydroxyl-vitamin D production, more and more studies have shown that the role of vitamin $\mathrm{D}$ is not limited to bone health [1]. Vitamin D can regulate immune function [2], hematopoietic system [3], cancer development and progression [4], glucose homeostasis through insulin production and insulin resistance [5] and cognitive function [6]. Thus vitamin D deficiency may be related to many diseases, such as asthma [7], diabetes mellitus [8], cardiovascular diseases [9], cancers [10, 11].

Epidemiological data in recent years have shown that vitamin D deficiency is widespread in the population, including pregnant women. A retrospective cohort study conducted in USA with 235 cases reported $30 \%$ of the pregnant women had adequate vitamin $\mathrm{D}$ level with serum 25(OH) D concentration more than $75 \mathrm{nmol} / \mathrm{L}$ [12]. Result from a national cross-sectional survey in Belgium revealed that $25.9 \%$ of women had $25(\mathrm{OH}) \mathrm{D}$ more than $75 \mathrm{nmol} / \mathrm{L}$ [13]. And a cross-sectional observation study from China found that in 5823 cases only $0.9 \%$ of pregnant women had adequate vitamin $\mathrm{D}$ status with $25(\mathrm{OH}) \mathrm{D}$ more than $80 \mathrm{nmol} / \mathrm{l}$ during the second trimester of pregnancy in 2011-2012 [14]. Thus, vitamin $\mathrm{D}$ deficiency in pregnancy has been a worldwide problem. Maternal vitamin D deficiency may be associated with a variety of adverse pregnancy outcomes, including pre-eclampsia [15, 16], preterm birth [17], gestational diabetes mellitus $[15,18]$ and bacterial vaginitis during pregnancy $[15,19]$. The vitamin $D$ level in fetus is exclusively dependent on the mother so maternal $25(\mathrm{OH})$ D level can potentially impact fetal development [20-22]. The offspring of pregnant women who are vitamin $\mathrm{D}$ deficient may have high risks of small for gestational age $[15,23]$, low birth weight $[15,23]$ and respiratory infections [19].

Recently more and more side effects of vitamin D deficiency have been recognized, and more attention has been paid on the vitamin $\mathrm{D}$ deficient pregnant women. But whether vitamin D nutritional status in Chinese pregnant women has improved during recent years is not clear. This observational study was designed to evaluate the prevalence of vitamin D deficiency at 16th week of gestation among a large group of pregnant women in Shanghai and the associations of vitamin D deficiency with some pregnancy outcomes (gestational diabetes and low birth weight) were analyzed, and hope to provide epidemiological evidence of vitamin D deficiency in Chinese pregnant women.

\section{Methods}

\section{Study population}

Participants who joined the regular pregnancy check-up in Shanghai Changning District Maternal and Child Health Hospital from January 2014 to December 2017 were recruited. This hospital located in Shanghai, the eastern China with the latitude at $31.1^{\circ} \mathrm{N}$. This hospital accepted pregnant women for prenatal care around all the districts of Shanghai. All the pregnant women who came to this hospital for prenatal examination at 16th week gestation were invited to test the vitamin D status. And we collected the test results retrospectively. Gestational age was calculated by the last menstrual date. The inclusion criteria of this study includes: (1) Han nationality; (2) lived in Shanghai for more than 1 year. The exclusion criteria includes: (1) chronic metabolic diseases affecting the metabolism of vitamin D, such as hyperthyroidism, hyperparathyroidism, chronic kidney disease and liver failure, etc.; (2) mental diseases; (3) either of the pregnant woman or her spouse had been diagnosed congenital deformities or genetic metabolic diseases; (4) either of the pregnant woman or her spouse had been addicted to smoking, alcohol or drug before or during the pregnancy. The Ethics Committee of Tongji Hospital, Tongji University School of Medicine declared that no formal ethics approval was required in this particular case. This study is a retrospective and observational study, and patient consent is not signed by each patient. All examination items were derived from routine prenatal care.

\section{Categorization of vitamin D}

$25(\mathrm{OH}) \mathrm{D}$ is the most abundant circulating form of vitamin $\mathrm{D}$ in the human body and serum $25(\mathrm{OH}) \mathrm{D}$ concentration has be a reliable indicator to assess the status of vitamin D. According to the concentration of serum $25(\mathrm{OH}) \mathrm{D}$, the vitamin $\mathrm{D}$ status can be divided into four levels: severe deficiency ( $<25 \mathrm{nmol} / \mathrm{L})$, deficiency (25-50 $\mathrm{nmol} / \mathrm{L})$, insufficiency $(50-75 \mathrm{nmol} / \mathrm{L})$ and adequate $(\geq 75 \mathrm{nmol} / \mathrm{L})$. And $50 \mathrm{nmol} / \mathrm{L}$ is considered as a threshold of deficiency and non-deficiency.

\section{Definition of seasons and age groups}

The seasons of sampling were defined as spring (March, April, May), summer (June, July, August), autumn (September, October, November) and winter (December, January, February). All participants were categorized into four age groups: 18-24 years old group, 25-29 years old group, 30-35 years old group, and > 35 years old group.

\section{Pregnancy outcomes}

Diagnosis of gestational diabetes followed the guideline demonstrated by American Diabetes Association. The glucose tolerance test was performed at 24-28th week 
gestation, and $75 \mathrm{~g}$ of glucose was given orally under fasting condition. Participant was diagnosed gestational diabetes if plasma glucose concentrations met one of the following values: $\geq 5.1 \mathrm{mmol} / \mathrm{l}$ on fasting, $\geq 10 \mathrm{mmol} / \mathrm{l}$ at $1 \mathrm{~h}$ and $\geq 8.5 \mathrm{mmol} / \mathrm{l}$ at $2 \mathrm{~h}$. Low birth weight of newborn was defined as birth weight lower than $2500 \mathrm{~g}$.

\section{Estimating the concentration of $25(\mathrm{OH}) \mathrm{D}$}

Blood samples were collected from all participants in fasting condition at 16 th week gestation. And the samples were stored at $-80^{\circ} \mathrm{C}$ until the serum $25(\mathrm{OH})$ D concentrations were measured by electrochemiluminescence assay (Roche Diagnostics, Cat. No. 05894913), and the period between blood collection and test was within 3 days. The assay has a sensitivity of $4 \mathrm{ng} / \mathrm{ml}$, and intra and inter-assay coefficient of variation of as 6.6 and $5.4 \%$.

\section{Statistical analysis}

The statistical analysis was performed using Statistical Package for the Social Science (SPSS), version 20.0. Mean \pm $\mathrm{SD}$ was used to describe continuous variables. Median, interquartile range and percentiles (p25-p75) were used to describe $25(\mathrm{OH}) \mathrm{D}$ concentrations because the distribution did not satisfy the criteria of normal distribution and nonparametric Kruskall-Wallis test was performed. Categorical variables were expressed as percentages and the proportions were compared using Chi-square test. Multiple logistic regression analysis was applied to access the relationship between relevant factors (season, age, year) and vitamin D status, and whether vitamin $\mathrm{D}$ status had association with the two pregnancy outcomes. $P<0.05$ was regarded to be statistically significant for all performed tests.

\section{Results}

Thirty-four thousand four hundred seventeen pregnant women were included in this observational study. The mean age of the participations was $30.57 \pm 3.52$ years (range:19-46 years). The median concentration of 25(OH) D was $42.87 \mathrm{nmol} / \mathrm{L}$ (32.88-51.90 nmol/L). 9.9\% of the population were severe deficient $(<25 \mathrm{nmol} / \mathrm{L})$, $60.1 \%$ were deficient $(25-50 \mathrm{nmol} / \mathrm{L}), 28.4 \%$ were insufficient $(50-75 \mathrm{nmol} / \mathrm{L})$ and only $1.6 \%$ of the subjects were adequate $(\geq 75 \mathrm{nmol} / \mathrm{L})$ (Table 1$)$.

Serum 25(OH) D concentration between seasons was significant different analyzed by Kruskal-Wallis test $(P<$ $0.001)$. And different proportion of categorical $25(\mathrm{OH})$ $\mathrm{D}$ levels was found by Chi-square test $(\mathrm{P}<0.001)$. Compared to the winter season, serum $25(\mathrm{OH}) \mathrm{D}$ level was lower in summer. The median concentration of $25(\mathrm{OH})$ $\mathrm{D}$ in summer was $41.76 \mathrm{nmol} / \mathrm{L}(32.60-50.80 \mathrm{nmol} / \mathrm{L})$, which was the lowest, with $10.7 \%$ of vitamin D severe deficiency and $62.1 \%$ of deficiency in the pregnant women respectively and only $1.8 \%$ of women had adequate vitamin $\mathrm{D}$. The highest $25(\mathrm{OH}) \mathrm{D}$ concentration occurred in winter and the median concentration was $45.10 \mathrm{nmol} / \mathrm{L}(33.28-54.96 \mathrm{nmol} / \mathrm{L})$, with $9.2 \%$ of vitamin D severe deficiency and $54.4 \%$ of deficiency (Table 1$)$.

Kruskal-Wallis test $(P<0.001)$ and Chi-square test $(\mathrm{P}<$ 0.001 ) both revealed the significant difference of vitamin $D$ levels between different age groups. The $>35$ years old group had the highest vitamin D level with $44.19 \mathrm{nmol} / \mathrm{L}$ (34.00-53.28 nmol/L) followed by $30-35$ years old group and 25-29 years old group, and the 18-24 years old group had the lowest vitamin D level. The percentage of pregnant women with severe deficiency and deficiency in $>35$ years old group was lower than the other groups (Table 1).

Vitamin D levels were significantly different between years. The serum $25(\mathrm{OH}) \mathrm{D}$ had the highest level in the year of 2017 and the lowest in 2016. The median concentration was $47.80 \mathrm{nmol} / \mathrm{L}(41.00-55.00 \mathrm{nmol} / \mathrm{L})$ in 2017 and $38.87 \mathrm{nmol} / \mathrm{L}(28.76-49.97 \mathrm{nmol} / \mathrm{L})$ in the year of 2016. Percentages of sever deficiency and deficiency were 2.1 and $56.9 \%$ respectively in 2017, and both of them were lower than the other years (Table 1).

The multiple logistic regression analysis demonstrated that season, categorical age and year were correlated with $25(\mathrm{OH})$ D status, all $P<0.001$ except for the season of summer. Compared with spring season, autumn and winter had lower risk of vitamin D deficiency, and the odds ratios were 0.841 and 0.607 respectively. Elder age could significantly decrease the risk of vitamin D deficiency and the odds ratios of $25-29,30-35,>35$ years old groups were $0.673,0.577$, and 0.550 respectively compared to the 18-24 years old group. Compared with the year of 2014, the odds ratios of the year of 2015, 2016, and 2017 were $1.186,1.224$, and 0.554 respectively (Table 2 ).

As to the pregnancy outcomes, both of gestational diabetes and low birth weight had no significant differences between vitamin $\mathrm{D}$ deficient and non-deficient groups according to the results of Chi-square test (Table 3). And no significant association was found between the $25(\mathrm{OH}) \mathrm{D}$ status and gestational diabetes or low birth weight by logistic regression analysis after adjusted for maternal age (Table 4).

\section{Discussion}

This study was conducted in a large group of samples with 34,417 Han participants to evaluate the prevalence of vitamin D deficiency in pregnant women in Shanghai, China. Our results revealed that most of the pregnant women (98.4\%) did not achieve adequate vitamin D status and $70 \%$ of them were severe deficient or deficient.

Latitude might be one of the important factors which contributes to the variation of $25(\mathrm{OH}) \mathrm{D}$ status between cities [24]. A previous study involving 1695 patients carried out in Shanghai from July 2008 to June 2009 showed that the average concentration was $17.57 \mathrm{ng} / \mathrm{mL}(43.93$ $\mathrm{nmol} / \mathrm{L}$, conversion of $25(\mathrm{OH}) \mathrm{D}: 1 \mathrm{ng} / \mathrm{mL}=2.5 \mathrm{nmol} / \mathrm{L})$ 
Table 1 Levels of serum 25(OH) D concentrations among different seasons, age groups and years

\begin{tabular}{|c|c|c|c|c|c|c|c|c|c|}
\hline Group & $\mathrm{N}$ & $\begin{array}{l}\text { Median (Interquartile Range) } \\
\text { (nmol/L) }\end{array}$ & $\begin{array}{l}\text { Percentile } \\
\text { (p25-p75) } \\
\text { (nmol/L) }\end{array}$ & $P$-value & $\begin{array}{l}\text { Severe } \\
\text { deficiency } \\
(<25 \mathrm{nmol} / \mathrm{L}) \\
(\%)\end{array}$ & $\begin{array}{l}\text { Deficiency } \\
\text { (25-50 nmol/L) } \\
\text { (\%) }\end{array}$ & $\begin{array}{l}\text { Insufficiency } \\
(50-75 \mathrm{nmol} / \mathrm{L}) \\
(\%)\end{array}$ & $\begin{array}{l}\text { Adequate } \\
(\geq 75 \mathrm{nmol} / \mathrm{L}) \\
(\%)\end{array}$ & $P$-value \\
\hline Season & & & & $<0.001$ & & & & & $<0.001$ \\
\hline Spring & 8299 & $42.00(19.73)$ & (31.07-50.80) & & 11.9 & 60.6 & 26.4 & 1.1 & \\
\hline Summer & $\begin{array}{l}10, \\
111\end{array}$ & $41.76(18.20)$ & (32.60-50.80) & & 10.7 & 62.1 & 25.4 & 1.8 & \\
\hline Autumn & 9188 & $43.13(17.80)$ & (34.30-52.10) & & 7.8 & 61.5 & 29.4 & 1.2 & \\
\hline Winter & 6819 & $45.10(21.67)$ & (33.28-54.96) & & 9.2 & 54.4 & 33.8 & 2.6 & \\
\hline \multicolumn{3}{|c|}{ Categorical age } & & $<0.001$ & & & & & $<0.001$ \\
\hline $18-24$ & 782 & $39.42(17.82)$ & (30.99-48.81) & & 11.9 & 66.6 & 20.2 & 1.3 & \\
\hline $25-29$ & $\begin{array}{l}14 \\
070\end{array}$ & $42.00(19.22)$ & $(31.84-51.06)$ & & 10.9 & 61.2 & 26.6 & 1.4 & \\
\hline $30-35$ & $\begin{array}{l}16 \\
283\end{array}$ & $43.46(18.77)$ & (33.75-52.53) & & 9.1 & 59.4 & 29.7 & 1.8 & \\
\hline$>35$ & 3282 & 44.19 (19.28) & (34.00-53.28) & & 9.2 & 57.2 & 31.7 & 2.0 & \\
\hline Year & & & & $<0.001$ & & & & & $<0.001$ \\
\hline 2014 & 6459 & 41.45 (17.96) & (32.97-50.93) & & 5.6 & 66.9 & 26.6 & 1.0 & \\
\hline 2015 & 8639 & $39.30(20.49)$ & $(29.67-50.17)$ & & 13.8 & 60.8 & 23.7 & 1.7 & \\
\hline 2016 & 9740 & $38.87(21.21)$ & (28.76-49.97) & & 17.1 & 58.0 & 23.0 & 2.0 & \\
\hline 2017 & 9579 & $47.80(14.00)$ & (41.00-55.00) & & 2.1 & 56.9 & 39.3 & 1.7 & \\
\hline Total & $\begin{array}{l}34 \\
417\end{array}$ & 42.87 (19.02) & $(32.88-51.90)$ & & 9.9 & 60.1 & 28.4 & 1.6 & \\
\hline
\end{tabular}

[25], which was quite consistent to our result. A study with 1924 patients enrolled from Nanjing (latitude $32.0^{\circ} \mathrm{N}$ ), a city almost at the same latitude as Shanghai, indicated that the median serum $25(\mathrm{OH}) \mathrm{D}$ was $43.4 \mathrm{nmol} / \mathrm{L}$ in the second pregnancy trimester [26]. Result of a study

Table 2 Multiple logistic regression analysis of factors for vitamin D deficiency

\begin{tabular}{llll}
\hline Predictors & $P$-value & Odds ratio & $95 \%$ confidence interval \\
\hline Season & & & \\
Spring & - & 1.000 & Reference \\
Summer & 0.451 & 1.026 & $0.960-1.096$ \\
Autumn & $<0.001$ & 0.841 & $0.786-0.899$ \\
Winter & $<0.001$ & 0.607 & $0.566-0.652$ \\
Categorical age & & & \\
$18-24$ & - & 1.000 & Reference \\
$25-29$ & $<0.001$ & 0.673 & $0.564-0.803$ \\
$30-35$ & $<0.001$ & 0.577 & $0.484-0.688$ \\
$>35$ & $<0.001$ & 0.550 & $0.456-0.664$ \\
Year & & & \\
2014 & - & 1.000 & Reference \\
2015 & $<0.001$ & 1.186 & $1.101-1.277$ \\
2016 & $<0.001$ & 1.224 & $1.139-1.316$ \\
2017 & $<0.001$ & 0.554 & $0.517-0.594$ \\
\hline
\end{tabular}

conducted in Guangzhou, a city in southern China (latitude $23.1^{\circ} \mathrm{N}$ ) revealed that the mean serum $25(\mathrm{OH}) \mathrm{D}$ during pregnancy was $27.03 \mathrm{ng} / \mathrm{mL}(67.58 \mathrm{nmol} /)$ [27] which is higher than Shanghai in our study, while another study from Beijing, a city in northern China (latitude $39.9^{\circ} \mathrm{N}$ ) found that the mean concentration of pregnant women was only $28.64 \mathrm{nmol} / \mathrm{L}$ [28], which is lower than our result. The above data shows vitamin $\mathrm{D}$ deficiency in pregnant women in China is very popular, same as other countries [29-31].

Season is another factor which contribute to the level of serum $25(\mathrm{OH}) \mathrm{D}$, usually with the highest level in summer and the lowest in winter [14, 27, 32, 33]. This can be explained by different ultraviolet radiation intensity between seasons. 25(OH) D in humans can be converted from 7-dehydrocholesterol in the skin by the photochemical action of ultraviolet B (UVB, 290-315 nm wavelength) radiation, which is the main source of vitamin D in humans in general [34] and is the best marker of vitamin D status. In summer, the ultraviolet intensity is higher, thus $25(\mathrm{OH}) \mathrm{D}$ is produced more during this period. However, the seasonal variation was not always observed the same. For instance, no statistically significant difference was found among seasons in a study from USA [12]. In this study, we found that the highest $25(\mathrm{OH})$ D level appeared in winter which was contrary to some previous studies. This could be explained by other factors affecting ultraviolet radiation intensity such 
Table 3 Rate of gestational diabetes and low birth weight in vitamin D deficient and non-deficient groups

\begin{tabular}{lllll}
\hline Pregnancy outcomes $(n, \%)$ & Overall subjects $(n=34,417)$ & $25(\mathrm{OH}) \mathrm{D}<50 \mathrm{nmol} / \mathrm{L}(n=24,084)$ & $25(\mathrm{OH}) \mathrm{D} \geq 50 \mathrm{nmol} / \mathrm{L}(n=10,333)$ & $P$-value \\
\hline Gestational diabetes & $4227(12.3 \%)$ & $2943(12.2 \%)$ & $1284(12.4 \%)$ & 0.593 \\
Low birth weight & $559(1.6 \%)$ & $387(1.6 \%)$ & $172(1.7 \%)$ & 0.706
\end{tabular}

as cloud cover. In Shanghai, rainy day was quite frequent in June and July, called plum rain season. And in China, light skin was regarded as more beautiful in women so sun blockers had been extensively used in summer such as umbrella, hat and sunscreen. In addition to vitamin D converted from the skin, part of the amount of vitamin $\mathrm{D}$ can be derived from diet and dietary supplements as well [35]. More persons choose to increase vitamin D intake in winter to compensate for the reduced ultraviolet exposure. The reasons above may contribute to the lower $25(\mathrm{OH}) \mathrm{D}$ level in summer and narrowed the gap between median $25(\mathrm{OH}) \mathrm{D}$ concentrations in different seasons.

We also found that the participants with the elderly pregnant age had relatively higher proportion of sufficient $25(\mathrm{OH}) \mathrm{D}$ status. Pregnant women in $>35$ years old group had the highest serum $25(\mathrm{OH}) \mathrm{D}$ concentration. This suggested that elderly pregnant women probably paid more attention to pregnancy care. They might expose themselves more to sunlight and more of them have vitamin D supplement from food or other multivitamins comparing to the younger pregnant women who might care more about their skin color change under sunshine. The result also revealed significant difference between years probably owning to different atmospheric contamination and overcast affecting ultraviolet intensity in these 4 years. Different exposure level to sunlight and vitamin intake might have an important effect as well. The year of 2017 had the highest level with the median serum concentration reaching $47.80 \mathrm{nmol} / \mathrm{L}(41.00-55.00 \mathrm{nmol} / \mathrm{L})$ which might be attributed to the increased concern about vitamin D deficiency in recent years. However, even more attention had been paid on the vitamin $\mathrm{D}$ deficient in the pregnant women, most of them were still in the status of severe deficient or deficient.

Some study revealed that maternal $25(\mathrm{OH})$ D status was related with gestation diabetes and low birth weight $[15,18,23,27]$. However, in our study, no associations were found between vitamin $\mathrm{D}$ status with gestation diabetes and low birth weight.

The Institute of Medicine (IOM, USA) suggests that serum $25(\mathrm{OH})$ D level superior to $20 \mathrm{ng} / \mathrm{mL}(50 \mathrm{nmol} / \mathrm{L})$

Table 4 Multiple logistic regression analysis of relationship between vitamin D level and pregnancy outcomes

\begin{tabular}{llll}
\hline Pregnancy outcomes & $P$-value & Odds ratio & $95 \%$ confidence interval \\
\hline Gestational diabetes & 0.530 & 1.023 & $0.953-1.098$ \\
Low birth weight & 0.796 & 0.976 & $0.814-1.171$ \\
\hline
\end{tabular}

can be adequate [36]. However the Endocrine Society (USA) considers the threshold level should be $30 \mathrm{ng} / \mathrm{mL}$ $(75 \mathrm{nmol} / \mathrm{L})$ [20]. And the Endocrine Society has suggested that pregnant women require at least $600 \mathrm{IU}$ vitamin $\mathrm{D}$ per day and at least $1500-2000$ IU vitamin D per day is necessary to maintain a concentration of $25(\mathrm{OH}) \mathrm{D}$ higher than $30 \mathrm{ng} / \mathrm{mL}(75 \mathrm{nmol} / \mathrm{L})$ [20]. Gestational vitamin D intake may have a protective role in offspring health such as reduce the risk of multiple sclerosis [37] and other autoimmune diseases. According to the result from a cohort study of 1669 mother-child pairs in Finland, higher maternal intake of vitamin D during pregnancy could reduce the risk of allergic outcomes in the children by 5 years old [38]. Meanwhile, evidence from a small perspective study suggested that exposure to optimal $25(\mathrm{OH}) \mathrm{D}(>75 \mathrm{nmol} / \mathrm{L})$ in pregnancy could be an increased risk of atopic disorders such as eczema and asthma [39]. More research is needed to determine a reasonable vitamin $\mathrm{D}$ intake guideline which can promote the health of mother and child and avoid adverse effects caused by excessive vitamin D intake in the meantime. To date, there is no guideline about vitamin D supplement during gestation period in China and the clinical criterion for vitamin D deficiency in pregnant women is still uncertain and debatable.

The main limitation of this study is the lack of demographic and characteristic details of study population, including sunlight exposure status, vitamin D supplement from food and multivitamins and body mass index. Another limitaion is the $25(\mathrm{OH}) \mathrm{D}$ level in this study is detected by the Roche assay, thus the detected $25(\mathrm{OH}) \mathrm{D}$ level in the pregnant women may be lower than their real level because of the increased DBP level in the pregnant women [40]. And also we have to mentione here that an external QC for detecting 25(OH) D level with Roche assay is not available when we conducted this study, thus the differences of $25(\mathrm{OH}) \mathrm{D}$ level in this study over time may be due to drifts in the calibration or changes in the generation of Roche assays. And more information about ultraviolet intensity in 2014-2017 is needed as well. However, large sample size with 34,417 cases in this study can warn us the popularity of vitamin D deficiency in Chinese pregnant women and further research may be planned based on the results in this study.

\section{Conclusions}

In conclusion, we found that pregnant women in Shanghai were generally deficient in vitamin D status. And temporarily there was no evidence that vitamin $\mathrm{D}$ deficiency had 
association with gestational diabetes and low birth weight. The results suggest that most of the pregnant women may need enough vitamin $\mathrm{D}$ supplements to achieve adequate vitamin $\mathrm{D}$ status and to at least partly avoid the complications related to vitamin $\mathrm{D}$ deficiency in the pregnant women.

\section{Acknowledgements}

Not applicable.

\section{Authors' contributions}

$H L, J M$ and $L S$ designed this study. $H L, M J, R H, Y W, G L, M X, L Y, J Y$ and LS analyzed and interpreted the patient data. $\mathrm{HL}$ and $\mathrm{MJ}$ were major contributors in writing the manuscript. The authors read and approved the final manuscript.

\section{Funding}

This work was funded by Shanghai Municipal Health Commission to L. song (201840217), Clinical Science and Technology Innovation Program of Hospital Development Center to L. song (SHDC12018X10), the fund for clinical study from Tongji Hospital to L. song (ITJ (ZD)1904) and the Fundamental Research Funds for the Central Universities of Tongji University to L. song (No. 22120180355). The funding supported for data collection and analysis and paper writing.

\section{Availability of data and materials}

The datasets used and analysed during the current study are available from the corresponding author on reasonable request.

\section{Ethics approval and consent to participate}

The Ethics Committee of Tongji Hospital, Tongji University School of Medicine declared that no formal ethics approval was required in this particular case. This study is a retrospective and observational study, and patient consent is not signed by each patient. All examination items were derived from routine prenatal care.

\section{Consent for publication}

Not applicable.

\section{Competing interests}

The authors declare that they have no competing interests.

\section{Author details}

'Department of Endocrinology, Tongji Hospital, Tongji University School of Medicine, Shanghai 200065, China. ${ }^{2}$ Division of Spine, Department of Orthopedics, Tongji Hospital affiliated to Tongji University School of Medicine, Shanghai 200065, China. ${ }^{3}$ Key Laboratory of Spine and Spinal Cord Injury Repair and Regeneration (Tongji University) Ministry of Education, Shanghai 200065, China. ${ }^{4}$ Shanghai Changning District Maternal and Child Health Hospital, Shanghai 200065, China. ${ }^{5}$ Tongji Hospital, Tongji University School of Medicine, Shanghai 200092, China.

Received: 21 December 2019 Accepted: 24 March 2020

\section{Published online: 04 June 2020}

\section{References}

1. Guessous I. Role of vitamin D deficiency in extraskeletal complications: predictor of health outcome or marker of health status? Biomed Res Int 2015;2015:563403.

2. Prietl B, Treiber G, Pieber TR, Amrein K. Vitamin D and immune function. Nutrients. 2013;5:2502-21.

3. Hall AC, Juckett MB. The role of vitamin D in hematologic disease and stem cell transplantation. Nutrients. 2013;5:2206-21.

4. Feldman D, Krishnan AV, Swami S, Giovannucci E, Feldman BJ. The role of vitamin D in reducing cancer risk and progression. Nat Rev Cancer. 2014;14:342-57.

5. Sung CC, Liao MT, Lu KC, Wu CC. Role of vitamin D in insulin resistance. J Biomed Biotechnol. 2012;2012:634195.

6. Laughlin GA, Kritz-Silverstein D, Bergstrom J, Reas ET, Jassal SK, BarrettConnor $\mathrm{E}$, et al. Vitamin D insufficiency and cognitive function trajectories in older adults: the rancho Bernardo study. J Alzheimers Dis. 2017;58:871-83.
7. Kerley CP, Elnazir B, Faul J, Cormican L. Vitamin D as an adjunctive therapy in asthma. Part 1: a review of potential mechanisms. Pulm Pharmacol Ther. 2015; 32:60-74.

8. CV H. Vitamin D and diabetes mellitus. Hormones (Athens). 2014:13:163-81.

9. Pilz S, Marz W, Wellnitz B, Seelhorst U, Fahrleitner-Pammer A, Dimai HP, et al. Association of vitamin D deficiency with heart failure and sudden cardiac death in a large cross-sectional study of patients referred for coronary angiography. J Clin Endocrinol Metab. 2008;93:3927-35.

10. Zhang L, Wang S, Che X, Li X. Vitamin D and lung cancer risk: a comprehensive review and meta-analysis. Cell Physiol Biochem. 2015;36:299-305.

11. Abu El Maaty MA, Wolfl S. Vitamin D as a novel regulator of tumor metabolism: insights on potential mechanisms and implications for anticancer therapy. Int J Mol Sci. 2017;18:2184.

12. Flood-Nichols SK, Tinnemore D, Huang RR, Napolitano PG, Ippolito DL. Vitamin D deficiency in early pregnancy. PLoS One. 2015;10:e0123763.

13. Vandevijvere S, Amsalkhir S, Van Oyen H, Moreno-Reyes R. High prevalence of vitamin $D$ deficiency in pregnant women: a national cross-sectional survey. PLoS One. 2012;7:e43868.

14. Xiao JP, Zang J, Pei JJ, Xu F, Zhu Y, Liao XP. Low maternal vitamin D status during the second trimester of pregnancy: a cross-sectional study in Wuxi, China. PLoS One. 2015;10:e0117748.

15. Aghajafari F, Nagulesapillai T, Ronksley PE, Tough SC, O'Beirne M, Rabi DM. Association between maternal serum 25-hydroxyvitamin D level and pregnancy and neonatal outcomes: systematic review and meta-analysis of observational studies. BMJ. 2013;346:f1169.

16. Pena HR, de Lima MC, Brandt KG, de Antunes MM, da Silva GA. Influence of preeclampsia and gestational obesity in maternal and newborn levels of vitamin D. BMC Pregnancy Childbirth. 2015;15:112.

17. Baczynska-Strzecha M, Kalinka J. Assessment of correlation between vitamin D level and prevalence of preterm births in the population of pregnant women in Poland. Int J Occup Med Environ Health. 2017;30:933-41.

18. Arnold DL, Enquobahrie DA, Qiu C, Huang J, Grote N, VanderStoep A, et al. Early pregnancy maternal vitamin D concentrations and risk of gestational diabetes mellitus. Paediatr Perinat Epidemiol. 2015;29:200-10.

19. Skowronska-Jozwiak E, Lebiedzinska K, Smyczynska J, Lewandowski KC, Glowacka E, Lewinski A. Effects of maternal vitamin D status on pregnancy outcomes, health of pregnant women and their offspring. Neuro Endocrinol Lett. 2014;35:367-72.

20. Holick MF, Binkley NC, Bischoff-Ferrari HA, Gordon CM, Hanley DA, Heaney $\mathrm{RP}$, et al. Evaluation, treatment, and prevention of vitamin D deficiency: an Endocrine Society clinical practice guideline. J Clin Endocrinol Metab. 2011; 96:1911-30.

21. Bennett SE, McPeake J, McCance DR, Manderson JG, Johnston P, McGalliard $R$, et al. Maternal vitamin D status in type 1 diabetic pregnancy: impact on neonatal vitamin D status and association with maternal glycaemic control. PLoS One. 2013;8:e74068.

22. Larque $\mathrm{E}$, Morales $\mathrm{E}$, Leis $\mathrm{R}$, Blanco-Carnero JE. Maternal and Foetal health implications of vitamin D status during pregnancy. Ann Nutr Metab. 2018;72:179-92.

23. Chen $\mathrm{YH}$, Fu L, Hao JH, Yu Z, Zhu P, Wang H, et al. Maternal vitamin D deficiency during pregnancy elevates the risks of small for gestational age and low birth weight infants in Chinese population. J Clin Endocrinol Metab. 2015;100:1912-9.

24. Yeum KJ, Song BC, Joo NS. Impact of geographic location on vitamin D status and bone mineral density. Int J Environ Res Public Health. 2016;13:184.

25. Tao M, Shao H, Gu J, Zhen Z. Vitamin D status of pregnant women in Shanghai, China. J Matern Fetal Neonatal Med. 2012;25:237-9.

26. Yuan Y, Liu H, Ji C, Guo X, Hu L, Wen J, et al. Association of Maternal Serum 25-hydroxyvitamin $\mathrm{D}$ concentrations in second trimester with delivery mode in a Chinese population. Int J Med Sci. 2017:14:1008-14.

27. Zhou J, Su L, Liu M, Liu Y, Cao X, Wang Z, et al. Associations between 25hydroxyvitamin $D$ levels and pregnancy outcomes: a prospective observational study in southern China. Eur J Clin Nutr. 2014;68:925-30

28. Song SJ, Si S, Liu J, Chen X, Zhou L, Jia G, et al. Vitamin D status in Chinese pregnant women and their newborns in Beijing and their relationships to birth size. Public Health Nutr. 2013;16:687-92.

29. Bartoszewicz Z, Kondracka A, Krasnodebska-Kiljanska M, Niedzwiedzka B, Popow M, Ambroziak $U$, et al. Vitamin D insufficiency in healthy pregnant women living in Warsaw. Ginekol Pol. 2013;84:363-7.

30. Richard A, Rohrmann S, Quack Lotscher KC. Prevalence of vitamin D deficiency and its associations with skin color in pregnant women in the first trimester in a sample from Switzerland. Nutrients. 2017;9:260. 
31. Loudyi FM, Kassouati J, Kabiri M, Chahid N, Kharbach A, Aguenaou H, et al. Vitamin D status in Moroccan pregnant women and newborns: reports of 102 cases. Pan Afr Med J. 2016;24:170.

32. Wierzejska R, Jarosz M, Sawicki W, Bachanek M, Siuba-Strzelinska M. Vitamin D concentration in maternal and umbilical cord blood by season. Int J Environ Res Public Health. 2017;14:1121.

33. Zhu T, Liu TJ, Ge X, Kong J, Zhang LJ, Zhao Q. High prevalence of maternal vitamin D deficiency in preterm births in Northeast China, Shenyang. Int J Clin Exp Pathol. 2015;8:1459-65.

34. Gilchrest BA. Sun exposure and vitamin D sufficiency. Am J Clin Nutr. 2008; 88:570-7.

35. Urrutia-Pereira M, Sole D. Vitamin D deficiency in pregnancy and its impact on the fetus, the newborn and in childhood. Rev Paul Pediatr. 2015;33:10413.

36. Ross AC, Manson JE, Abrams SA, Aloia JF, Brannon PM, Clinton SK, et al. The 2011 report on dietary reference intakes for calcium and vitamin D from the Institute of Medicine: what clinicians need to know. J Clin Endocrinol Metab. 2011;96:53-8

37. Mirzaei F, Michels KB, Munger K, O'Reilly E, Chitnis T, Forman MR, et al. Gestational vitamin $D$ and the risk of multiple sclerosis in offspring. Ann Neurol. 2011;70:30-40.

38. Erkkola M, Kaila M, Nwaru BI, Kronberg-Kippila C, Ahonen S, Nevalainen J, et al. Maternal vitamin $D$ intake during pregnancy is inversely associated with asthma and allergic rhinitis in 5-year-old children. Clin Exp Allergy. 2009:39: $875-82$

39. Gale CR, Robinson SM, Harvey NC, Javaid MK, Jiang B, Martyn CN, et al. Maternal vitamin D status during pregnancy and child outcomes. Eur J Clin Nutr. 2008;62:68-77.

40. Cavalier E, Lukas P, Crine Y, Peeters S, Carlisi A, Le Goff C, et al. Evaluation of automated immunoassays for $25(\mathrm{OH})$-vitamin $\mathrm{D}$ determination in different critical populations before and after standardization of the assays. Clin Chim Acta. 2014;431:60-5.

\section{Publisher's Note}

Springer Nature remains neutral with regard to jurisdictional claims in published maps and institutional affiliations.

Ready to submit your research? Choose BMC and benefit from:

- fast, convenient online submission

- thorough peer review by experienced researchers in your field

- rapid publication on acceptance

- support for research data, including large and complex data types

- gold Open Access which fosters wider collaboration and increased citations

- maximum visibility for your research: over $100 \mathrm{M}$ website views per year

At $\mathrm{BMC}$, research is always in progress.

Learn more biomedcentral.com/submissions 